\title{
The future in the past in Louisiana French
}

\author{
Kevin Rottet \\ Indiana University \\ krottet@indiana.edu
}

\section{Introduction}

In this paper I examine two non-standard uses of the past conditional in Louisiana French (LF). ${ }^{1}$ Although robustly present in oral and written texts, these are uses which have almost entirely escaped the notice of grammatical descriptions and previous linguistic work. I will also explore the origins of these patterns and connect them to possible influence of language contact with American English.

Some grammatical descriptions of LF have failed to spot any differences between the LF and the Standard French (SF) conditional, ${ }^{2}$ but other sources point to a handful of ways in which the uses of the conditional and the past conditional differ from SF. The most commonly cited difference is that conditional verb forms are typically used in both clauses of an if-then statement, not just in the result clause as in SF (Brandon, 1955 : 470; Phillips, 1936: 60 ; Conwell and Juilland, 1963: 153-154). A few sources also mention that conditionals are occasionally used in place of the subjunctive (Brandon, 1955 vol. 1, p. 470 ff.; Conwell and Juilland, 1963: 154), perhaps most readily when the main clause verb is also in the conditional. These cited differences concern the modal conditional (the conditional as a mood).

The two patterns I wish to focus on, are, first, the use of the past conditional for the future-in-the-past, regardless of whether the action described is anterior; and secondly, the occasional use of the past conditional in place of the imparfait. These uses involve the temporal conditional (the conditional as a tense).

\section{The data}

Grammatical descriptions of SF (e.g. Judge \& Healey, 1995 ; L'Huillier, 1999) typically distinguish between the conditional as a mood (the modal conditional), and the conditional as a tense (the temporal conditional). The modal conditional is used primarily in the following ways:

- to express hypotheses, both with and without the conjunction «si » being overtly expressed

- to mitigate or soften requests as a politeness strategy

- to express unfulfilled wishes

- $\quad$ to express epistemic modality ${ }^{3}$

These uses will be illustrated briefly with data from LF. For if-then statements, French (both SF and LF, and many other languages as well), makes a three-way distinction between what are commonly known as open conditions, closed conditions, and counterfactual or contrary-to-fact conditions. Conditional verbs are not used in open conditions, which generally have a present tense verb in the "if" clause and a present, a future, or an imperative in the result clause.

(1) Et si vous voulez aller là-bas et voir les bateaux, on peut aller là-bas après qu'on a fini ici. (Lafourche Parish) ${ }^{4}$ 
In closed conditions in LF, both the result clause and the «si » clause traditionally appear in the present conditional; occasionally the imparfait appears in the «si » clause instead, as shown in (3) :

(2) si je le voirais asteur je pourrais dire son nom (Lafourche Parish)

(3) S'il n'y avait que les cannes [i.e. variétés de canne à sucre] du pays on serait obligé d'arrêter de faire des cannes (Guilbeau 1950: 344)

Counterfactuals typically have both the result clause and the «si » clause in the past conditional, as shown in (4). The « si » clause is occasionally found with the imperfect or the pluperfect, as in (5) :

(4) si cette vieille là l'aurait pas sauvé là, elle aurait mouri jeune. (Terrebonne Parish)

(5) “Qui vous-autres aurait fait si j'avais pas de licence?" Eux-autres dit: "On aurait pris la viande que t'as dans le FREEZER." (Terrebonne Parish)

The conditional and the past conditional can also be used to present unrealized hypothetical scenarios even when no « si » clause is present. Examples of this are illustrated in (6) through (10).

(6) Dans ce temps-là il (y) avait assez de moustiques, il faulait que t'ayes des baires pour te couvère avec, les moustiques t'auraient mangé. (Terrebonne Parish)

(7) Il était seul. Il voulait s'en revenir, mais il pouvait pas, parce qu'il avait pas moyen de sortir. Il lui aurait fallu des ailes d'oiseau pour sortir. (Acadia Parish, Ancelet $1994: 65$ )

(8) Il dit que quelqu'un a venu peindre sa bêtaille vert. Il dit, "Qui-ce qui aurait fait ça?" (St Landry Parish, Ancelet 1994 : 86)

(9) Il y en a plein comme, well, ma maman voulait être, aller être une NURSE. Mais ses parents ont jamais voulu la laisser aller. Et elle aurait pu aller à l'Hôpital de Charité. Elle aurait pu aller et apprendre mais ils voulaient pas elle va. (St James Parish)

(10) Dans ce temps-là t'aurais pu prendre ton porte-monnaie et t'aurais pu te coucher sur la banquette [ $=$ le trottoir] et mettre ton porte-monnaie sur toi et dormir, et personne aurait touché ton porte-monnaie. La ville [=la Nouvelle Orléans], y avait pas rien, y avait pas de tracas du tout dans la ville. La seule manière t'aurais pu te mettre en tracas c'est si t'aurais tombé là et assayer de t'occuper avec la femme d'un autre bougre ou quelque chose, là t'aurais proche sûr eu une bataille. Mais à part de ça y avait pas de malfaisants dans la ville, c'était tout du monde qu'avait été élevé là, et c'était tout à fait différent. (Terrebonne Parish)

Use of the modal conditional to mitigate or soften requests is illustrated in (11) and (12):

(11) "Je m'ai trouvé un chien, mais," il dit, "t'aimerais pas aller à la chasse de canards demain?" (Evangeline Parish, Ancelet 1994 : 74)

(12) J'ai venu voir si t'aurais pas quelque chose pour me donner à manger. (St Landry Parish, Ancelet 1994 : 155)

And to express unfulfilled wishes:

(13) J'aurais bien voulu qu'alle soye là que j'aurais pu vous la montrer et vous expliquer exactement quoi-ce, comment alle était. Mais alle est partie se faire arranger, tous les ans on l'envoye à Thibodaux pour qu'ils l'arrangeont. (Assumption Parish) 
(14) Asteur je voudrais bien que j'aurais eu fini mais ça m'a jamais arrêté, j'a fait une vraie bonne vie. (Terrebonne Parish) ${ }^{5}$

Conditionals can be used to express epistemic modality, specifically to report an event that one has learned by hearsay when one does not wish to be held responsible for the accuracy of the report. This is often called the journalistic conditional:

(15) "Si vous autres veux aller à tel et tel bois," il dit (c'était là que Geneviève aurait été tuée, il croyait), "là j’irai." (Iberville Parish, Ancelet, 1994 : 49)

These uses of the modal conditional in LF do not differ notably from equivalent uses in SF. As mentioned earlier, LF does present one modal use of the conditional which differs from SF, namely a tendency to use the conditional instead of the subjunctive when the matrix verb is also conditional:

(16) Mais mon je voudrais bien que j’aurais élevé son père (Terrebonne Parish)

But it is in the temporal conditional that LF norms depart most strikingly from SF, and it is to those that we now turn.

The temporal conditional refers to the use of conditional verb forms to express the future-in-the-past. The future-in-the-past occurs with verbs of cognition (such as savoir, penser, croire, décider) and verba dicendi (such as dire, demander, répondre, expliquer). In canonical SF grammar, a past tense verbum dicendi causes a future tense of a direct quote to change to a conditional when reported indirectly. Similarly, a future perfect becomes a conditional perfect (i.e. past conditional), and a futur proche (the present tense of aller plus an infinitive) becomes the imperfect of aller plus an infinitive. These three patterns are illustrated below:

(a) Il a dit: "Nous partirons dans une heure."

$\rightarrow \quad$ Il a dit que nous partirions dans une heure.

(b) Il a dit: "Elle sera déjà morte."

$\rightarrow \quad$ Il a dit qu'elle serait déjà morte.

(c) Il a dit: "Je vais partir dans une heure."

$\rightarrow \quad$ Il a dit qu'il allait partir dans une heure.

The descriptive literature on LF does not say much about how the future-in-the-past is handled. I am aware of only two references, the first being the doctoral dissertation of John Guilbeau describing the LF spoken in Lafourche Parish, Louisiana, which he spoke natively (1950: 220):

The past future in a subordinate clause after a past tense is expressed by the imperfect of /ale/ plus the infinitive: on croyait qu'il allait capoter 'We thought it was going to turn over.' Il les a dit de pas pleurer, qu'il allait les emmener 'He told them not to cry, that he was going to take them., ${ }^{6}$

Guilbeau does not mention the use of the conditional to mark the future-in-the-past. Indeed, expressing the future-in-the-past with the present conditional does not seem to be very common in LF, though this pattern is certainly attested, as in (17):

(17) [E]ux-autres a dit que ça coûterait plein plus bon marché nous déloger à nousautres en quelque place plutôt d'arranger notre place. (Terrebonne Parish)

In the second published reference to the future-in-the-past in LF, Rottet (2001) reported on a study of intergenerational changes in the declining LF of Terrebonne and Lafourche Parishes, thus including the subdialect described by Guilbeau (1950). Rottet's study included administering a translation task to bilinguals covering an age span from 8 to 88 . One of the variables examined was the conditional. Although most of the uses of the conditional reported on are for the modal rather than the 
temporal conditional, Rottet $(2001: 245)$ does give results for the temporal conditional item « They told me they would be late for the party. » Relevant results are reproduced in Table 1.

\begin{tabular}{|c|c|c|c|c|c|}
\hline Age group & $\begin{array}{c}\text { allait }+ \\
\text { infinitive }\end{array}$ & $\begin{array}{c}\text { Past } \\
\text { conditional }\end{array}$ & $\begin{array}{c}\text { Present } \\
\text { conditional }\end{array}$ & futur proche & Other \\
\hline $55+$ & $36 \%(12)$ & $27 \%(9)$ & $9 \%(3)$ & $24 \%(8)$ & $3 \%(1)$ \\
\hline $30-54$ & $19 \%(6)$ & $19 \%(6)$ & $6 \%(2)$ & $53 \%(17)$ & $3 \%(1)$ \\
\hline$<30$ & 0 & $26 \%(5)$ & 0 & $53 \%(10)$ & $21 \%(4)$ \\
\hline
\end{tabular}

Table $1:$ Translation equivalents in « They told me they would be late for the party » (Rottet $2001: 245$ )

Among speakers aged 55 or older, whom Rottet calls Older Fluent Speakers (OFS), or those whose speech is taken to reflect the traditional norms of the dialect, 12 speakers (a majority) used allait + infinitive, which is consistent with Guilbeau's description for this dialect region. Three OFS used the present conditional. But what is most striking it that nine OFS used the past conditional. Combining all three age groups, a total of 20 speakers used a past conditional whereas only five used a present conditional. This is despite the fact that, manifestly, the meaning of the subordinate verb in the cue sentence is not future anterior in the past, but simply future-in-the-past. A past conditional is therefore unexpected and would not be possible in SF.

But this unexpected pattern is in fact even more robustly found in language samples from other parishes of francophone Louisiana.

(18) Là, j'ai décidé j'aurais arrêté [=que j'arrêterais] ça, j'aurais repris [=je reprendrais] à jouer du violon. (Evangeline Parish, Valdman et al. $2009: 547$ )

(19) Elle a préparé à souper de bonne heure. Elle connaissait que le vieux diable aurait arrivé [=arriverait] plus tard et elle voulait que les enfants soient tous couchés pour quand il serait arrivé pour pas qu'il s'aperçoive qu'il y en avait un d'étrange. (Lafayette Parish, Ancelet 1994 : 33-34)

(20) Un jour, il a frappé l'huile sur sa terre et il est venu millionaire. Il a décidé il aurait traversé [=qu'il traverserait] le monde pour se trouver un chien meilleur que le chien à Pascal. (Evangeline Parish, Ancelet 1994 : 74)

(21) Il s'avait couvert de sable à Holly Beach croyant que ça aurait guéri [=guérirait] ses rheumatismes. (Lafayette Parish, Valdman et al. 2009 : 166)

(22) Un jour, j'ai décidé j'aurais vendu [=que je vendrais] tous les bêtes. J'étais lasse et puis c'était dur pour nous-autres. (St Landry Parish, Valdman et al. 2009 :361)

(23) J'étais sûr qu'alle s'aurait débauché [=se débaucherait] quand alle a rencontré cet homme-là. (Vermilion Parish, Valdman et al. $2009: 181$ )

(24) Je lui avais dit qu'il s'aurait tout bousillé [=qu'il se couvrirait de boue] s'il jouait déhors. (Lafayette Parish, Valdman et al. 2009 : 84)

(25) Il lui a demandé si il aurait voulu [=voudrait] prendre un orphelin, et, and [je] pense c'était un peu dur pour décider, bien qu'il avait cinq enfants. (Avoyelles Parish, Valdman et al. $2009: 70$ )

This pattern is also found in literary compositions and songs composed in LF :

(26) Mon garçon est après graduer du collège demain. J'i ai promis que j'aurais été [=je serais] là. (Guidry 1982) 
(27) Quand j'ai quitté de la maison [...] j'avais dit que j'aurais jamais rev'nu. [=je ne reviendrais jamais]. (folksong : « J'ai fait une grosse erreur »)

(28) C'est pour ça que je t'avais fait cette robe-là pour le baptême à Belle. T'avais pas le temps de coudre, Ada, t'étais trop occupée. Et, je savais que t'aurais aimé [=tu aimerais] ce petit dessin rose. (Broussard, Toups \& Leblanc 1999)

(29) Je comprends pas comment vous-autres a cru que le prêtre aurait consenté [=consentirait] qu'un Méthodiste se marie dans l'église Catholique. (Broussard, Toups \& Leblanc 1999)

(30) Je trouvais emasse de les traitments curieux et des fois je doubtais si ça aurait travailler [=marcherait / marche (subjonctif)]. (Whatley 1983)

Use of the past conditional for the future-in-the-past appears to be the pattern of choice in much of francophone Louisiana, occurring more often than either the present conditional or allait + infinitive. ${ }^{7}$ To give a sense of the frequency of this pattern I have quantified the uses of the past conditional, and the expression of future-in-the-past, in Ancelet (1994), a collection of folktales gathered orally from speakers in a number of different parishes throughout Francophone Louisiana and containing about 43,000 words (excluding those texts which were narrated in Louisiana Creole). This collection lends itself well to the study of future-in-the-past because in the narrative style of folktales, reported speech and cognitive verbs reporting what characters decided or what they thought would happen are fairly frequent. In this small corpus there are a total of 60 occurrences of the past conditional. The functional breakdown of these 60 occurrences is as follows:

Temporal uses of the past conditional

- future-in-the-past

- past habitual

Modal uses of the past conditional

- hypothesis without SI

- hypothesis with SI

- unrealized wish

- epistemic modality

The modal uses occurring in Ancelet (1994) primarily agree with SF uses, although in three instances the past conditional occurs where a present modal conditional might have been expected (but note that in two of these, the verb pouvoir seems to be implied. I include Ancelet's published translations of these three examples) :

(31) Et si tu observais cette lumière-là, cette petite lumière t'aurait perdu [=perdrait], ça. (Vermilion Parish, Ancelet 1994 : 157)

"And if you watched that light, the light would cause you to lose your way."

(32) Ça fait, après il est mort, le vieux homme regarde la vieille femme. Il dit, "Vieille, je t'ai dit c'était un enfant on aurait pas sauvé [= pourrions pas?], ça!" (St Martin Parish, Ancelet 1994 : 87)

"So after he died, the old man looked at the old woman. He said, "Honey, I told you that this was a child we wouldn't be able to save!"” 
(33) J'ai entendu dire ayoù il y avait du poisson à vendre. Je voulais tu viens avec moi. On aurait été [=pourrait aller?] l'acheter. (Evangeline Parish, Ancelet 1994 : 110)

"I heard where there was some fish to sell. I wanted you to come with me. We'll go to buy some."

Use of the past conditional for the present modal conditional is occasionally attested in other collections of texts :

(34) Si les ouaouarons grognaient pas, c'était ein signe qu'ein orage s'en venait dans ein deux jours. S'ils grognaient durant l'orage, la mouillasse aurait pas duré $[=$ ne durerait pas] longtemps. (Whatley 1983)

But it is the use of the past conditional for the future-in-the-past which is the really striking pattern in these data. Indeed, not a single one of the 33 occurrences of past conditional for future-in-the-past actually expresses future anterior in the past. In every case, the equivalent in SF would be a present conditional, not a past conditional. ${ }^{8}$ These 33 cases represent $87 \%(33 / 38)$ of the instances of future-inthe-past in Ancelet (1994). There are an additional five occurrences of future-in-the-past expressed in other ways. Three of these are instances of allait + infinitive, as in (35) :

(35) Ça fait qu'elle, elle savait qu'ils allaient la tuer. (Iberville Parish, Ancelet 1994 :

45)

There is one occurrence of the idiom être parti (plus infinitive), which means 'to be off (to do something)' in $\mathrm{LF}^{9}$. This is shown in (36) :

(36) Un jour, le petit garçon dit à sa mère, il était parti faire la chasse [= 'he was off to go hunting'] dans le bois. (Lafayette Parish, Ancelet 1994 : 36)

Finally, there is a single occurrence of the present conditional being used for future-in-the-past :

(37) Et un de ces jours, il allait venir à en avoir assez, et il pourrait aller au bal. (St Landry, Ancelet 1994 : 85)

The present conditional occurs 63 times in Ancelet (1994), but only one token (shown in (37) above) is used to express future-in-the-past. The other 62 occurrences represent one or another category of the modal conditional.

To show that this is not just an idiosyncracy of the Ancelet (1994) collection, I quantified instances from Loupe (1932), a collection of folktales from Livingston Parish, a parish not represented in the Ancelet (1994) collection. In this short collection of folktales narrated by a half dozen elderly speakers, there are ten occurrences of the future-in-the-past; one uses allait + infinitive and the other nine use the past conditional. Again, none of these represents a future anterior in the past. In every case, the SF equivalent would simply be the present conditional.

To summarize the findings so far, it appears that the past conditional is the pattern of choice for expressing the future-in-the-past for many speakers of LF, and that this pattern was already in place in the speech of elderly speakers in 1932. Ninety percent (9/10) of the instances of the future-in-the-past in Loupe (1932) and 87\% (33/38) in Ancelet (1994) were expressed with the past conditional. The past conditional appears largely to have taken the place of the present conditional in this temporal function. In modal uses of the conditional, on the other hand, this replacement is sporadically attested but not very common.

Let us turn briefly to one other temporal use of the past conditional in LF which departs significantly from SF, though it is less frequent than its use for the future-in-the-past. The past conditional is also 
attested to express the past habitual, where the imparfait (or in a few instances, the plus-que-parfait) would be expected. Note that in a number of examples, the past conditional alternates with the imparfait in the same passage. ${ }^{10}$

(38) S'il avait envie de jouer, il sortait son accordéon et il aurait joué [=jouait] dessus. S'il avait pas envie de jouer, jouait pas du tout. (Acadia Parish, Rojas et al. 2003)

(39) Oh à-peu-près n'importe qui que t'avais, t'aurais été [=tu allais] là-bas. Mal aux dents, mal d'oreille, mal au ventre, et là il connaissait les tisanes et tout. [...] Il aurait pris [=prenait] une racine d'un certain bois. Il te donnait et t'aurais pris [=tu prenais] ça et faire la tisane avec ça. Et tu buvais ça pour tant de jours, il t'aurait dit $[=$ il te disait] combien de jours de boire ça pour. (Terrebonne Parish)

(40) Dans les vieux temps, le monde déménageait des bâtisses. Ça aurait mis [=ils mettaient] des rolons en-dessous et ça l'aurait halé [=ils le halaient] avec des mulets. (Lafayette Parish, Valdman et al. 2009: 560)

(41) Elle aurait coulé [ =coulait] son jus pour voir s'il n'avait pas des petits morceaux de feuilles. (St Landry Parish, Valdman et al. 2009 : 160)

(42) On avait des chiens à lapins. On aurait tué [=tuait] peut-être huit, dix lapins en allant là-bas. Et s'aurait fait [ $=$ on se faisait $]$ une grosse cuite, bien mangé. (St Landry Parish, Valdman et al. $2009: 175$ )

(43) Le samedi d'après, un autre aurait tué [=tuait] son veau et il aurait séparé [=séparait] la viande parmi les autres, c'étiont comme un groupe. (Acadia Parish, Valdman et al. $2009: 439$ )

(44) Il avait le foyer. Il l'aurait cordé [=cordait] plein de bois jusqu'à en haut. (St Landry Parish, Valdman et al. $2009: 155$ )

(45) Je l'aurais tortillé [=je l'entortillais] avec une liane et puis je le halais. (St Landry Parish, Valdman et al. $2009: 620$ )

In the Ancelet (1994) collection, seven out of 60 occurrences of the past conditional are used to signal past habitual, a not insignificant number. (Nevertheless, there are far more occurrences of the past habitual being expressed with the imparfait, as in SF). Yet this use is only mentioned in one source on LF, Conwell and Juilland (1963: 155-156), and therefore, like the use of the past conditional for future-in-thepast, it has largely escaped the attention of descriptions of LF grammar.

In the next section I will consider the possible origins of these innovative uses of the past conditional in LF.

\section{Discussion}

To explore the possible origins of these patterns let us take them separately, beginning with the past conditional to mark the future-in-the-past.

First of all, it is necessary to determine whether this use of the past conditional is simply a survival of an older and more widely attested pattern. We have seen that the adoption of the past conditional to express future-in-the-past is already an established usage in Loupe (1932). Because texts in LF are very rare before that date, it is probably not possible to determine when this development began, though since Loupe's speakers were elderly this suggests a speech pattern going back at least to the mid-19th century. However, Louisiana is not the only place where this pattern is found. It is also fairly common in Carrière's (1937) corpus of texts from Old Mines, Missouri: 
(46) 'L a été vouère l'vieux rouè; i'a d'mandé s'i' l'aurait pas quitté rester au loin d'sa maisonne pour trois nuits. (p. 138)

(47) [...] i'a dzit qu'si j'allais pas qu'ri son château, pis l'porter sus sa place d'armes, i' m'aurait pendzu. (p. 154)

(48) Il a offert eune bonne somme d'argent pour n'importe qui y'aurait donné ein avis pour attraper Sam'son. (p. 38)

(49) 'L a d'mandé à la princesse si a s'aurait mariée.-."Ah! Oui," a dzit, "m'as m'marier, mais pas avant qu'j'aye mon château d'vant vot' place d'armes icitte." (p. 153)

And although I have found no overt mentions of the pattern in any of the descriptive literature on Maritime Acadian, there are a few sporadic occurrences in Acadian texts from the Maritime Provinces:

(50) Y ava eune bâtisse pis y ava du foin qui poussa dsus, eh? Pis i wonderiont comment-ç-qu'il ariont pu faire pour aller en haut asteure pou que la vache mange le foin. (Thomas 1983: 204)

(51) j'avais quatorze quinze ans je faisais les foins . pis là pis les soirs des fois j.ai vu honze heures douze heures le soir on/ on avait pas fini surtout si que ta pluie pren/ prendriait hein si que/ si qu.i arait mouillé demain ben/ si t.avais (Wiesmath 2006 text 1 , lines 643-646)

But the pattern appears to be unknown in Quebec French and European French. The fact that it is only attested in three sociolinguistically similar communities where French has been in intense contact with English and is largely cut off from SF norms leads us to consider other explanations.

There are two other explanations which I argue probably worked in concert, an internal and an external one. LF (and other related vernaculars such as those spoken in Missouri and Acadia) is a variety in which the verbal system has moved quite far away from synthetic towards analytic paradigms. ${ }^{11}$ Indeed, many languages, including Modern SF, reveal a general preference for analytic over synthetic forms. This is described by Chaudenson, Mougeon \& Beniak (1993: 96) as a "prédilection pour l'expression analytique (et donc transparente) des valeurs aspectuelles et temporelles". They note that Frei (1929) had already talked about a "besoin d'invariabilité" in popular language, which included "que [les] divers éléments soient exprimés distinctivement et non en cumul." It is clear from the language contact literature that this preference for analysis over synthesis is intensified in contact settings ; for instance, creole languages are highly analytic, with very little inflectional morphology.

The preference for a past conditional over a present conditional (albeit in specific, temporal uses) can readily be understood as another instance of this general trend in that the information « future-in-thepast » or «temporal conditional » is packaged as a separate morpheme from the main verb, in the form of the auxiliary, with the main verb then being expressed as a past participle. Note further that the LF auxiliary almost invariably takes the form /ore/. The LF $1 \mathrm{pl}$ is invariably expressed with the pronoun on rather than nous, thus taking a 3sg verb, and the ending for vous has been regularized from [(r)je] to [(r)e] to agree with the other persons. Therefore variation is found in the LF endings of the conditional only in the $3 \mathrm{pl}$, where some subdialects use the ending [(r)jõ], e.g. auriont. But this form is relatively uncommon, and for most speakers of LF the auxiliary is always /ore/ for all persons. ${ }^{12}$ Additionally, most verbs in LF are conjugated with avoir rather than être (though there is some regional variation on this point). Thus, in addition to being an analytic form, the past conditional is also much simpler than the present conditional, which involves manipulation of some irregular stems (cf. irait, viendrait, tiendrait, saurait, pourrait, ferait among others). 
Of course, the form allait + infinitive is also a periphrastic form, and it could arguably have served just as well as the past conditional for marking the future-in-the-past. Is there any other reason for the robust emergence of the past conditional for marking the future-in-the-past in LF ? In fact, the answer is yes, for this strategy permits increased isomorphism with English, the language with which LF has been in intense contact for more than two hundred years. One of the results of intense language contact frequently mentioned in the literature is convergence, or the "process whereby languages in contact gradually become more like each other in terms of grammatical categories and constructions » (Aikhenvald 2006 : 334). Theoretically convergence aims at an ultimate goal of isomorphism or complete intertranslatability. Although few languages are described as having reached this extreme endpoint, the contact literature is filled with examples of partial convergence. In the most familiar contact settings it is generally an embattled minority language which converges towards a language of wider currency and greater social status. In a small number of cases where neither language is especially more dominant or prestigious than the other, both languages may converge toward each other.

The reasons for convergence are not difficult to find. When people have two languages to learn instead of one, and this situation is prolonged over a long period of time, convergence is one way of lessening the cognitive burden of bilingualism. When carried to the extreme, the two languages would have a single underlying system with a single set of abstract concepts, differing only in terms of the superficial phonetic strings used to label concepts.

It is therefore likely not a coincidence that the developments of the past conditional explored in this paper are uses which both have the English word WOULD as their translation equivalent. It would appear that, in contact with American English, LF speakers have established a partial equivalence between the English word WOULD and the form /ore/. ${ }^{13}$ This equivalence has increased isomorphism in the verb system of these two languages. As a calque on an English pattern, the match is of course not perfect, since the English conditional consists of the invariable form would plus a bare infinitive (thus would go, would be, would have) whereas the French pattern consists of /ore/ plus a past participle, not an infinitive. For the vast majority of verbs, namely all those in the -er category, the infinitive and the past participle are homophonous, so it is only with -ir and -re verbs that this lack of total convergence is even detectable in the spoken language. It is not unusual, however, for convergence in language contact settings to be partial ; total convergence is rarely if ever achieved.

I suggested above that the internal explanation, namely increasing analyticity, and the external cause, namely increased isomorphism with English, likely reinforced each other in bringing about the two uses of the past conditional identified in this paper. Borrowing or calquing of patterns is facilitated when the new pattern follows the direction the system is going anyway. Quite similarly to the present case, Basque is argued to have increased analyticity in the verb phrase due to intense contact with Spanish, although there too, " parallelism is not complete », for instance with Basque word orders differing from Spanish even when analytic patterns are calqued (Jendraschek $2006: 147)$.

One of the questions that this use of the past conditional raises is why the replacement of the present conditional by the past conditional has not happened to any great extent with the modal conditional, but only with the temporal conditional. Put differently, if the past conditional simplifies the expression of the conditional, conforms to the language's larger trend towards analyticity, and increases isomorphism with English, why not replace the present conditional with the past conditional in all uses, rather than just in temporal uses? I suggest that part of the reason involves the semantic load of the distinction between present and past conditional. For the temporal conditional, the future anterior in the past is quite rare ; Haillet (2002 : 11) found only two occurrences in a SF corpus of nearly 4000 conditional examples. Consequently very little would seem to hinge on the difference between the future-in-the-past and the future anterior in the past - a distinction which could at any rate usually be made with the adverb déjà if an anterior reading is necessary (il a dit qu'il aurait déjà mangé). Thus, little or no meaning is actually sacrificed when this distinction is collapsed in favor of the simpler past conditional. On the other hand, for the modal conditional, the distinction between present and past conditional alone makes the difference 
between closed conditions and counterfactual conditions. This seems to be a salient distinction, to abandon which would represent some loss of meaning and some potential misunderstandings. (Compare « If I got sick, I would not go to class » and « If I had gotten sick, I would not have gone to class ». These manifestly do not describe the same state of affairs).

I will close with one other advantage to analyticity in the LF verb phrase. Using an analytical conditional permits easy incorporation of English verbs into an otherwise LF sentence, since English verbs are typically not inflected when they appear in LF discourse:

(52) Je serais content que tu pourrais aller te prendre une saucée avec mon. Ma fille et son mari l'autre bord, ils pourraient ENJOY ça. (Terrebonne Parish)

(53) Pascal a guetté ça. L'autre le guettait aussi, voir si ça l'aurait impress. (Evangeline Parish, Ancelet 1994 : 74)

LF norms for bilingual discourse do not permit attaching LF morphology to unassimilated English verbs, preferring to treat them as «bare forms » (Picone 1997). A periphrastic pattern for the conditional allows a speaker to express the English verbs enjoy and impress in the conditional, which would not be possible if the latter required synthetic expression.

\section{Conclusions}

In this paper I have shown that the past conditional has largely taken the place of the present conditional to express future-in-the-past in LF. The past conditional has also acquired an added function of being an alternate way of expressing the past habitual, thus competing to some extent with the imparfait. I have argued that these two developments can be attributed to an internal change in LF, namely replacing a synthetic form by an analytic one, which is reinforced by an external pattern, namely the fact that in American English the conditional is expressed analytically using the invariant morpheme would.

\section{Bibliography}

Aikhenvald, A. Y. (2006). "Grammars in contact: A cross-linguistic perspective. " Chapter 1 in Grammars in Contact, ed. by A. Y. Aikhenvald and R.M.W. Dixon. Oxford : Oxford University Press, 1-66.

Ancelet, B. J. (1994). Cajun and Creole Folktales. Jackson: University Press of Mississippi.

Brandon, E. (1955). Moeurs et langue de la Paroisse Vermillon en Louisiane. Ph.D. thesis, Laval University, Quebec.

Broussard, E., M. Toups \& J. Leblanc. (1999). La dernière quilte. In May G. Waggoner (ed.), Une fantaisie collective : Anthologie du drame cadien. Lafayette : Centre d'Etudes Louisianaises, 238-280.

Carrière, J. M. (1937). Tales from the French Folk-lore of Missouri. New York: AMS Press.

Chaudenson, R., R. Mougeon \& E. Beniak. (1993). Vers une approche panlectale de la variation du français. Paris : Didier Erudition.

Chaudoir, C.C. (1937). A study of the grammar of the Avoyelles French dialect. Baton Rouge: M.A. thesis, Louisiana State University.

Conwell, M. and A. Juilland. (1963). Louisiana French Grammar. The Hague : Mouton.

Frei, H. (1929). La grammaire des fautes. Geneva : Bellegarde.

Guidry, R. (1982). C'est p'us pareil. Lafayette : Centre d'Etudes Louisianaises.

Guilbeau, J. (1950). The French spoken in Lafourche Parish, Louisiana. Ph.D. thesis, University of North Carolina (Chapel Hill). 
Haillet, P.P. (2002). Le conditionnel en français : une approche polyphonique. Paris : Ophrys.

Jendraschek, G. (2006). «Basque in contact with Romance languages. » Chapter 5 in Grammars in Contact, ed. by A. Y. Aikhenvald and R.M.W. Dixon. Oxford : Oxford University Press, 143-162.

Judge, A. and F.G. Healey. (1995). A Reference Grammar of Modern French. NTC Publishing Group.

L’Huillier, M. (1999). Advanced French Grammar. Cambridge University Press.

Loupe, S. (1932). Acadian Folklore of La Côte française. M.A. thesis. Baton Rouge : Louisiana State University.

Phillips, H. (1936). Etude du parler de la Paroisse Evangéline (Louisiane). Paris: Droz.

Picone, M. D. (1997). Code-switching and loss of Inflection in Louisiana French, in Language Variety in the South Revisited, ed. by Cynthia Bernstein, Tom Nunnally, and Robin Sabino; Tuscaloosa: University of Alabama Press, 1997, 152-162.

Rojas, D. M., Piston-Hatlen, D., Propst, K., Gonin, M., \& Lindner, T. (Eds.). (2003). A la découverte du français cadien à travers la parole/Discovering Cajun French through the Spoken Word [CD-Rom] (Project Director: Albert Valdman, in collaboration with Barry Jean Ancelet, Amanda LaFleur, Michael D. Picone, Kevin J. Rottet \& Dominique Ryon). Bloomington: Indiana University Creole Institute.

Rottet, K. J. (2001). Language Shift in the Coastal Marshes of Louisiana. New York: Peter Lang.

Thomas, G. (1983). Les deux traditions: Le conte populaire chez les Franco-Terreneuviens. Montréal: Les Editions Bellarmin.

Valdman, A., K. J. Rottet, B.J. Ancelet, R. Guidry, T. A. Klingler, A. LaFleur, T. Lindner, M. D. Picone, D. Ryon. (2009). Dictionary of Louisiana French: As spoken in Cajun, Creole, and American Indian Communities. Jackson : University Press of Mississippi.

Whatley, R. (1983). Du chicot: A collection of essays. Baton Rouge: The Chicot Press.

Wiesmath, R. (2006). Le français acadien: Analyse syntaxique d'un corpus oral recueilli au Nouveau-Brunswick, Canada. Paris: L'Harmattan.

1 The term Louisiana French is more or less synonymous with Cajun French, though since some pockets of speakers eschew the label «Cajun », I prefer the former term for its greater inclusivity. The term does not include Louisiana Creole, which is usually regarded as a separate language and in any case has its own very distinct norms.

2 For instance, Chaudoir (1937:65) wrote : "The function of the conditional tense in the [Avoyelles French dialect] is practically the same as in the [Standard French]."

3 Haillet (2002) considers the epistemic use, which he calls le conditionnel d'altérité énonciative, to be distinct from le conditionnel temporel and le conditionnel d'hypothèse. His three-way categorization is motivated by paraphrases of these three uses, which are different in each case. Since I am primarily interested in the temporal conditional in this paper, this distinction is not crucial here.

${ }^{4}$ Cited examples not attributed to a published text are from fieldwork. Note that the civil parish is the Louisiana equivalent of the county found in other American states.

${ }^{5}$ Very occasionally, a supercompound or pluperfect conditional is used instead of a past conditional, apparently to emphasize the anteriority of the event so marked.

${ }^{6}$ I have converted Guilbeau's system of transcription, somewhat different from IPA, to SF orthography.

${ }^{7}$ The possible exception, as we saw in Guilbeau (1950) and Rottet (2001), is the Terrebonne-Lafourche dialect area, in which the traditional norms seem to favor allait + infinitive, though Rottet shows that the past conditional is found here as well.

8 The texts in Ancelet (1994) are translated into English, and in the majority of cases the English translations provided are also in the present conditional; in a few cases the translator rendered the past conditional as a past conditional in English as well.

${ }^{9}$ The auxiliary used to form the compound tenses of partir in LF is avoir, not être. The expression etre parti is simply an idiom in which parti functions like an adjective. Thus, il était parti means 'he was going / he was off'. 
${ }^{10}$ In LF, the past habitual and the past progressive are expressed differently. The past progressive is conveyed not with the imparfait but with the periphrasis être après + infinitive (j'étais après manger quand il a appelé 'I was eating when he called').

${ }^{11}$ For instance, the synthetic future has largely been ousted by the futur proche; progressive aspect is systematically expressed with the periphrasis être après + infinitive, meaning the imperfect is not used for past progressives but only for past habituals. Even then, there is some tendency to mark past habituals in LF with habitude. And the exhortative or $1 \mathrm{pl}$ imperative has been completely replaced by allons + infinitive, thus instead of Mangeons! LF as Allons manger.

12 For the six forms j'aurais, tu aurais, il/al aurait, on aurait, vous aurez, vous-autres aurait, ils auraient, Chaudoir (1937: 52) gives the single pronunciation [ore]; and similarly for the verb être, all persons take a verb form pronounced [sre] (p. 55). Likewise Phillips (1936:47) notes that « il n'y a qu'une forme pour chaque temps de verbe, à en juger par la prononciation. »

${ }^{13}$ Conwell and Juilland (1963: 155-156) made a similar claim for one of these uses: "Under the influence of the English would, habitual past actions may sometimes be expressed by the conditional perfect instead of the imperfect, e.g. ils auraient joué l'accordéon, [et] ils auraient dansé." 